\title{
Nondecussating retinal-fugal fiber syndrome (achiasmatic syndrome)
}

Rahul Nikam, MBBS, DNB, Vinay Kandula, MD, and Achala Donuru, MD

Neurology ${ }^{\circledR}$ 2018;90:979-980. doi:10.1212/WNL.0000000000005563
Correspondence

Dr. Nikam

rahulnikam@hotmail.com

Figure Achiasmatic syndrome

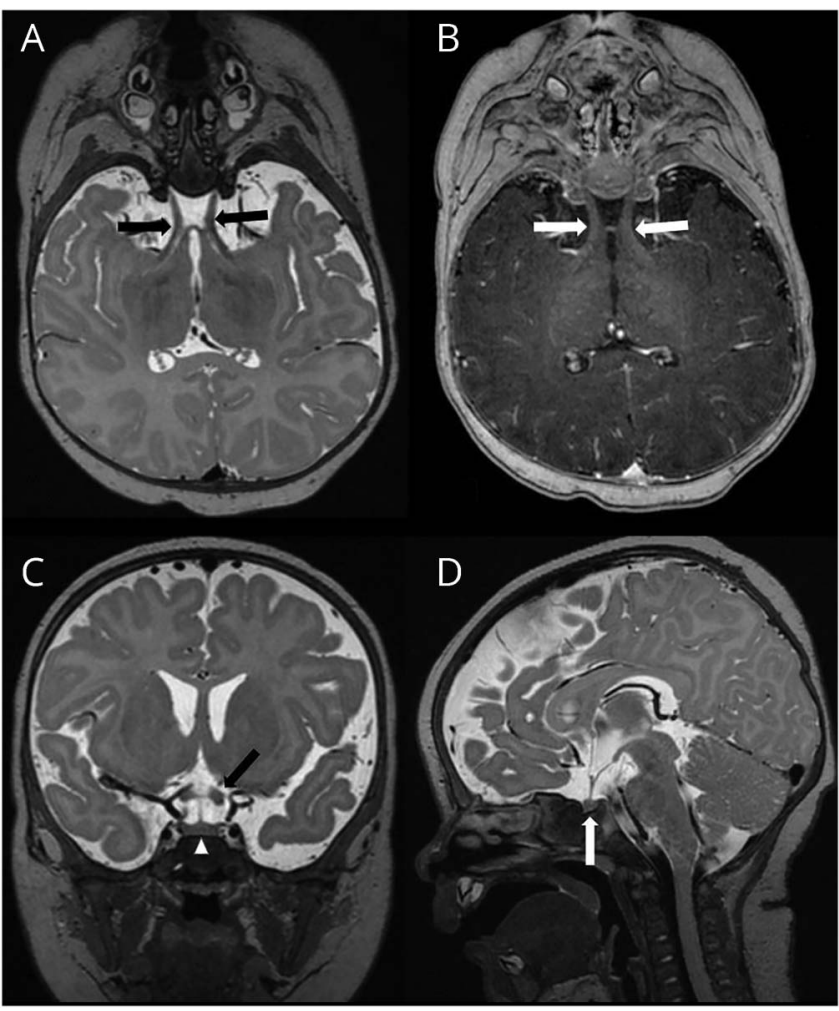

Axial T2-weighted (A) and postcontrast T1-weighted (B) images through the optic nerves depict failure of optic nerve fibers to decussate at the chiasm before continuing as optic tract (black and white arrows), a characteristic of achiasmatic syndrome. Coronal (C) and sagittal (D) T2-weighted images through the sella demonstrate absence of optic chiasm (black arrow: optic tract, white arrowhead and arrow: pituitary gland).

A 9-week-old girl presented with poor visual responsiveness and congenital seesaw nystagmus. Congenital seesaw nystagmus usually implies a structural anomaly, such as achiasma, and warrants evaluation with MRI (figure). ${ }^{1}$ Isolated absence of optic chiasm is extremely uncommon. ${ }^{2}$ In nondecussating retinal-fugal fiber syndrome (achiasmatic syndrome), there is failure of decussation of nasal retinal fibers, with the misrouted nasal fibers projecting and misaligning with projections from the temporal retina of the same eye, leading to reversal of the left and right half of visual field coordinates ("mirror reversal"). ${ }^{1}$ Mutation in a homeobox gene may underlie this aberration in pathfinding of retinal axons seen in achiasma. ${ }^{2}$

\section{Author contributions}

Rahul Nikam: critical revision for intellectual content. Vinay Kandula: supervision. Achala Donuru: concept and design.

From the Department of Medical Imaging (R.N., V.K.), Nemours A.I. DuPont Hospital for Children, Wilmington, DE; and Department of Radiology (A.D.), Thomas Jefferson University Hospitals, Philadelphia, PA.

Go to Neurology.org/N for full disclosures. Funding information and disclosures deemed relevant by the authors, if any, are provided at the end of the article. 


\section{Study Funding}

No targeted funding reported.

\section{Disclosure}

The authors report no disclosures relevant to the manuscript. Go to Neurology.org/N for full disclosures.

\section{References}

1. Balani A, Kumar AD, Marda SS, Alwala S. Nondecussating retinal-fugal fiber syndrome: clinical and neuroimaging clues to diagnosis. Indian J Ophthalmol 2015;63: 858-861.

2. Biega TJ, Khademian ZP, Vezina G. Isolated absence of the optic chiasm: a rare cause of congenital nystagmus. AJNR Am J Neuroradiol 2007;28: $392-393$

\section{Neurology $y^{\circledast}$ Online CME Program}

Earn CME while reading Neurology. This program is available only to online Neurology subscribers. Read the articles marked CME, go to Neurology.org, and click on CME. This will provide all of the information necessary to get started. The American Academy of Neurology (AAN) is accredited by the Accreditation Council for Continuing Medical Education (ACCME) to sponsor continuing medical education for physicians. Neurology is planned and produced in accordance with the ACCME Essentials. For more information, contact AAN Member Services at 800-879-1960.

\section{Share Your Artistic Expressions in Neurology 'Visions'}

AAN members are urged to submit medically or scientifically related artistic images, such as photographs, photomicrographs, and paintings, to the "Visions" section of Neurology $y^{\odot}$. These images are creative in nature, rather than the medically instructive images published in the NeuroImages section. The image or series of up to six images may be black and white or color and must fit into one published journal page. Accompanying description should be 100 words or less; the title should be a maximum of 96 characters including spaces and punctuation.

Please access the Author Center at NPub.org/authors for full submission information.

\section{Disputes \& Debates: Rapid online correspondence}

The editors encourage comments on recent articles through Disputes \& Debates:

Access an article at Neurology.org/N and click on "COMMENT" beneath the article header. Responses will be posted within 3 business days.

Before submitting a comment to Disputes \& Debates, remember the following:

- Disputes \& Debates is restricted to comments about studies published in Neurology within the last eight weeks

- Read previously posted comments; redundant comments will not be posted

- Your submission must be 200 words or less and have a maximum of five references; reference one must be the article on which you are commenting

- You can include a maximum of five authors (including yourself) 


\section{Neurology}

\section{Nondecussating retinal-fugal fiber syndrome (achiasmatic syndrome) \\ Rahul Nikam, Vinay Kandula and Achala Donuru \\ Neurology 2018;90;979-980 \\ DOI 10.1212/WNL.0000000000005563}

This information is current as of May 21, 2018

\section{Updated Information \& Services}

References

Subspecialty Collections

Permissions \& Licensing

Reprints including high resolution figures, can be found at: http://n.neurology.org/content/90/21/979.full

This article cites 2 articles, 0 of which you can access for free at: http://n.neurology.org/content/90/21/979.full\#ref-list-1

This article, along with others on similar topics, appears in the following collection(s):

All Neuro-ophthalmology

http://n.neurology.org/cgi/collection/all_neuroophthalmology

All Pediatric

http://n.neurology.org/cgi/collection/all_pediatric

MRI

http://n.neurology.org/cgi/collection/mri

Ocular motility

http://n.neurology.org/cgi/collection/ocular_motility

Optic nerve

http://n.neurology.org/cgi/collection/optic_nerve

Information about reproducing this article in parts (figures,tables) or in its entirety can be found online at:

http://www.neurology.org/about/about_the_journal\#permissions

Information about ordering reprints can be found online:

http://n.neurology.org/subscribers/advertise

Neurology ${ }^{\circledR}$ is the official journal of the American Academy of Neurology. Published continuously since 1951, it is now a weekly with 48 issues per year. Copyright (O) 2018 American Academy of Neurology. All rights reserved. Print ISSN: 0028-3878. Online ISSN: 1526-632X.

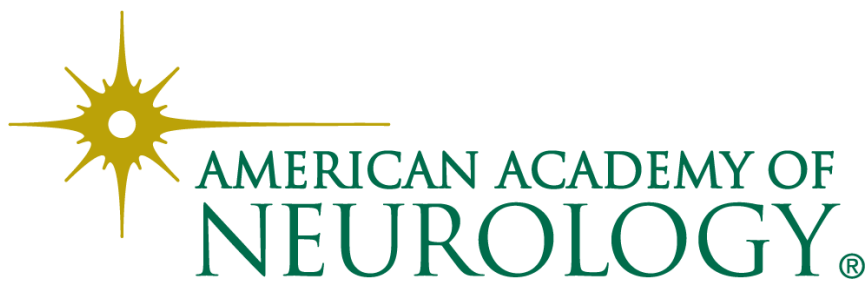

